\title{
The Effects of Self-esteem, Age and Gender on the Speaking Skills of Intermediate University EFL Learners
}

\author{
Bahareh Koosha \\ Isfahan University, Isfahan, Iran \\ Email: b_koosha_2006@yahoo.com \\ Saeed Ketabi \\ Isfahan University, Isfahan, Iran \\ Email: ketabi@fgn.ui.ac.ir \\ Zohreh Kassaian \\ Isfahan University, Isfahan, Iran \\ Email: zkassaian@yahoo.com
}

\begin{abstract}
This study aimed at investigating the relationship between self-esteem, age and gender on the one hand and speaking skills on the other hand. For this purpose, based on an OPT test twenty intermediate Persian learners of English were selected from among undergraduate EFL students studying towards a B.A. in teaching English as a foreign language at Islamic Azad University, Khorasgan Branch. Using a modified version of Farhady, et. al.'s scale (1995), measuring the five subskills of vocabulary, structure, pronunciation, fluency and comprehensibility, two raters evaluated the speaking ability of the participants at the end of the required course (Oral Production of Short Stories). The Sorensen's (2005) questionnaire for measuring selfesteem containing 50 items was also administered to the participants. The result showed a significant relationship between self-esteem and speaking skill with fluency exerting the most influence. There was also a reverse relationship between age and speaking skills. Concerning the relationship between gender and speaking skills, no statistically significant association was found. The study could have implications for English language teachers, learners and text book writers.
\end{abstract}

Index Terms—self-esteem, speaking skills, testing speaking, Persian learners of English

\section{INTRODUCTION}

Different terms such as 'self-concept', 'self efficacy', 'self-esteem' and 'self confidence' are often used interchangeably and inconsistently in the literature because they may refer to different ideas about how people think about themselves (Stern, 1995).

Some researchers view self-concept and self- efficacy as the same construct, but others view them as two different constructs (Bong \& Clark, 1999; Choi, 2005). Huitt (2004) distinguished the two terms 'self-concept' and 'self-esteem' by stating that 'self-concept' is the cognitive aspect of self, but 'self-esteem' is the affective aspect of self, which refers to one's feelings of self-worth. Self-confidence is not always what we think it is.

Some experts (e.g. Miyagawa, 2010) distinguish between self-confidence on one side and self-esteem on the other. Self-confidence is about what we can do by virtue of our efforts. What we are good and bad at. Self-confidence grows along with the quality of the effort. Self-esteem is more fundamental and is about the feeling of being worth something, just because we are who we are, and not because we have done something.

Nativists believe that any normal child can learn a first language because of the availability of what Chomsky (1959) refers to as UG. However, when it comes to the learning of foreign language, especially at the later stage, there are factors which can either inhibit or enhance the process of learning. These factors can be cognitive, affective, biological and socio-cultural variables (Stern, 1983)

A number of studies (Gonzalez-Pienda, Nunez, Gonzalez-Pumariega, 2000; El- Anzi's, 2005) have shown the effect of self-esteem, which is usually classified as an affective factor, as one of the crucial factors that determines success in academic performance in general. In this vein, scholars in educational psychology have attempted to analyze the different types of relationship that exist between self-esteem and performance. However, the results obtained so far do not seem to be conclusive as to which one of the two depends on the other, that is, it is not yet clear whether it is selfesteem which brings about academic achievement or, conversely, it is academic achievement which enhances selfesteem. For instance, Marsh, Kong, and Hau (2001) found that English achievement positively affected English selfesteem among their participants. Conversely, Marsh, Relich, and Smith (1983) in a study showed that it was the 
academic self-esteem that positively affected school performance. Whatever the case, it is almost certain that there is a significant relationship between these two variables.

Concerning the relationship between self-esteem and achievement in second language acquisition, the result of a study by Hayati and Ostadian (2008) revealed that students' listening comprehension was significantly influenced by their self-esteem, supporting earlier studies in this area.

Speaking skills may also be affected by the learners' age. In the words of Klein (1986) 'between the age of two and puberty the human brain shows the plasticity which allows a child to acquire his first language' (p.9). Romero (2006) also states that while adults find it difficult to achieve the ability to acquire and integrate complex data and cope with different aspects at the same time, children can do it unconsciously.

One component of speaking that seems to be affected the most by age is pronunciation. Some studies (e.g. Kuhl, 2004, p.832) have shown that 'young infants are especially sensitive to acoustic changes at the phonetic boundaries between categories'. Also, children are especially good at predicting syllable chunks. According to Kuhl (2004) "infants are sensitive to the sequential probabilities between adjacent syllables" (p. 834). Adults, on the other hand, as some scholars claim, cannot acquire a phonological development (Lightbown and Spada, 2006, p.69).

Other than investigating the possible impacts of age and self-esteem on the speaking skills, in this study an attempt was made to see if gender also plays a role in this connection. One of the few studies which have been conducted on the effect of gender on the production of oral skills is that of Gorjian, Moosavian and Shahramiri (2011). They investigated the effect of oral summery of short stories on male and female learners' speaking proficiency. The results of their study showed no significant difference between the two genders, although females slightly outperformed males.

One of the questions which remains to be investigated in this connection is related to the differential role that selfesteem may play in EFL production. More specifically, this study tries to see if self-esteem and age as well as gender can affect the learners' performance in the productive skill of speaking.

\section{LITERATURE REVIEW}

Many of those who learn a foreign language do so in order to be able to communicate with native speakers in real life situation. They wish to interact with the speech community in such a way that they are accepted as a member of that community. This implies that they are looking for acquiring communicative competence as used by Hymes (1972), in reaction to Chomsky's linguistics competence. What Hymes means is that linguistic competence is a prerequisite for communicative competence and has its own rules. These rules are those that native speakers acquire as they grow up in L1.

When it comes to learning a second language however, the situation is usually different. An adult second language learner has already mastered a first language together with the rules of use in communication, a situation which can easily interfere with those of using the first language, thus making it extremely difficult for the L2 learners to achieve native-like performance, especially when it comes to areas where there is a big difference between the two languages.

One area in speaking which has shown to be quite difficult to master completely is that of the pronunciation and intonation of the language. According to Spolsky (1989) only 5\% of nonnative speakers can achieve perfect mastery of these two features of language in speaking. This means that in order to arrive at an acceptable level of near native communication, L2 learner must possess certain biological, cognitive, affective and socio-cultural variables. Affective variables are considered as inhibition, risk taking, anxiety, extroversion/introversion, motivation and self-esteem. (Celce-Murcia (ed.), 1991; Stern, 1983; Nezu \&Nezu, 2003).

This article is basically concerned with self-esteem which comes under the umbrella term of affective (personality) variables. Maslow (1970) believes that in order to be a full functioning person, the learner needs to have satisfied certain needs. These needs, according to him, are basic needs which are (1) physiological such as the need to eat; (2) need for safety; (3) need for belongingness; (4) need for self-esteem and finally, (5) need for self-actualization. Concerning self-esteem, Maslow believes that all human beings desire respect and usually high evaluation of themselves and for esteem of others.

In recent years, self-esteem has attracted the attention of many scholars in psychology and education and many studies have been conducted to show the contribution of this characteristic to the learning of different subject matters including the learning of English (Kamarzarrin, 1994; Carter \& Nunan, 2001). A number of studies found that selfesteem affects academic performance in English among EFL students positively (Hui-Ju Liu, 2008; Chapman \& Tunmer,1997; Choi, 2005; De Fraine, Van Damme, \& Ongheda, 2007; Kurtz-Costes, \& Schneider, 1994; Marsh, 1990; Marsh \& Yeung, 1998). On the other hand, some studies showed that it is the English achievement that positively affects English self-esteem (Marsh, Kong and Hau, 2001). Helmke and Aken (1995) suggested that, although there is no agreement about the direction of causal ordering between academic self-esteem and academic achievement, one thing is certain that academic self-esteem is formed at least in part as a result of prior academic achievement.

Considering the relationship between self-esteem and oral communication, Niki Maleki \& Mohammadi (2009) found that the more successful learners had higher self-esteem than the less successful ones in performing oral communication tasks.

As mentioned above, two factors that might play an important role in relation to speaking skills are age and gender. Carroll (2008) believes that, in general, young children learn L2 better than older children and adults. He goes on to say 
that although "older learners seem to do better initially but they reach a plateau; younger learners eventually catch up and pass them" (p.331).

Concerning the relationship between the age of arrival in the target language country, and language ability, Hakuta, Bialystok, and Wiley (2003) conducted a study the results of which showed that there is a strong association between and two and that as the age of arrival increases, the level of proficiency decreases.

According to Romero (2006) it seems that for adults it is very difficult to learn to speak a new language simply because they feel they need to cope with many different aspects at one time, and in real conversation that seems to be impossible. The author believes that the differences between children learners and adult learners and the circumstances under which they learn a second language are quite obvious and therefore the results could also differ.

Concerning children, the fact that they are at the optimal time for learning, is what makes them outstanding learners. This optimal time is referred to as the critical period. It could be said that children learn the language without being aware of it when they "are exposed to the right kind of auditory information" (Kuhl, 2004, p. 836). This means that children learn the language through communication and interaction and in this way they acquire all the abilities they can potentially develop. This is also because children have the capacity for perceiving and imitating sounds. Some studies have shown that children are capable of predicting syllable boundaries (Kuhl, 2004, p. 834). Felta (2006) claims that children from the beginning of their development can integrate difficult information easily and unconsciously.

Concerning adults, on the other hand, we observe that they find it so difficult to acquire certain native sounds. Some scholars (e.g. Lenneberg, 1967) believe that the reason lies in the fact that distinguishing and producing some sounds become difficult after the critical period and therefore adults often have a foreign-like pronunciation Some researchers even consider phonological development in adults to be impossible (Lightbown and Spada, 2006, p.69).

However, other researchers hold the opposite view. Wolfgang Klein (1986) states that "the apparent facility with which children learn a second language is often attributed to biological factors, but an alternative explanation might be that, unlike adults, children have no need to fear the loss of their social identity" (p.6). These critics (e.g. Klein, 1986) argue that phonological facilities of children are bound to psychological reasons rather than biological ones. According to them, adults feel attached to their native identities, to their original social identities, and this is what prevents them from achieving perfection in L2 pronunciation. Klein (1986) maintains that 'suitably motivated adults are capable of mastering to perfection the pronunciation of the most exotic languages' (p.10). While Lenneberg (1967) claims that UG is available only before puberty, authors such as Felix (1988) reject such view. In this regard Felix (1988) states "If child and adult learners use different modules for the purpose of language acquisition, then we would expect adult learners to be unable to attain grammatical knowledge that arises only through the mediation of UG. If, in contrast, adults do attain this type of knowledge, then, we have reason to believe that UG continues to be active even after puberty"(p.279). It could be concluded that although the instances of adults speaking with native-like pronunciation are not very common, this does not mean that it is not possible.

Regarding the third factor, gender, a 1998 Canadian assessment of students' speech communication skills showed that there were many significant gender differences among individuals' listening skills (Hunter, Gambell, Randhawa, 2005). The study revealed that oral production of males was consistently below that of females According to Claes (1999) the evidence for inherent sex differences in language is not convincing.

Therefore, it is important to explore the relationship between both gender and age in relation to speaking. However it has to be mentioned at this point that compared with studies conducted in the areas of other language skills, few research has been conducted to investigate the relationship between the three factors of self-esteem, age, gender and speaking.

\section{RESEARCH QUESTIONS AND HYPOTHESES}

Based on what was mentioned above, this study makes an attempt to investigate the following questions:

1 - Is there any significant relationship between self-esteem and speaking skills among intermediate Persian EFL learners?

2- Is there any significant relationship between males and females in terms of speaking skills among intermediate Persian EFL learners?

3- Is there any significant relationship between age and speaking skills among intermediate Persian EFL learners?

Based on these questions, the following hypotheses were formulated

1 - There is no significant relationship between self-esteem and speaking skills of EFL learners.

2- There is no relationship between gender and speaking skills among EFL learners.

3- There is no relationship between age and speaking skill among Persian EFL learners.

\section{METHODS}

In order to decide whether or not the hypotheses formulated could be rejected, the following steps were taken for the selection of participants, materials and procedures used in the study.

\section{A. Participants}


Twenty participants, fifteen females and five males, were selected from among undergraduate EFL students studying towards a B.A. in teaching English as a foreign language in Khorasgan University. These participants were about to sit for the final exam of their required course of oral production of short stories, which is normally offered in the third semester of their studies.

\section{B. Instruments}

1- An OPT test was administered to determine the language proficiency of the learners.

2- A speaking scale developed by Farhady, Jafarpoor and Birjandi (1995) was used by the instructor teaching the course of oral production of short stories at Khorasan University. The same scale was also used by the researcher. This scale measures the participants' speaking ability in terms of the following components: a. Accent; b. Structure; c. Vocabulary; d. Fluency; and e. Comprehension.

Scores were given on a 6 point scale ranging from the least appropriate (1) to the most (6). However, based on the purposes of this study and also the results obtained from the pilot study this scale was modified. As far as modification is concerned, instead of accent the term pronunciation, which is more commonly used in such studies was used. Comprehension, too, as intended by Farhady et al. was interpreted to mean the extent to which the participants could comprehend what was said by the speaker.

3- A questionnaire taken from Sorensen (2005) containing 50 items was used to measure the degree of participants' self-esteem. The participants were also asked to mention their age and gender as it was necessary to seek the correlation between age and gender, and self esteem.

\section{Procedures}

1- In order to choose the participants, an OPT test was administered among undergraduate language learners studying in the last week of the required course of Oral Production of Short Stories. Based on the results, those scoring one SD bellow and one SD above the mean were selected. Then a sample consisting of 20 out of these participants was randomly chosen for the purpose of this study.

2- The instructor teaching this course at the mentioned university was asked to provide the scores of participants based on the speaking scale developed by Farhady, et. al. (1995) consisting of 5 components of accent, structure, fluency, vocabulary and comprehension.

3- The same participants were invited for an interview with the researcher who asked them to talk about one of the stories covered in the course based on their own choice.

The reason was that the researcher is basically interested in their production skill not necessarily in the content of what they produced. The researcher's scale for rating learners' performance on their production was the same as the one the course instructor used.

The scale used by the teacher and the rater requires careful attention to the following points suggested by Farhady et. al. (1995):

a. Each interview must be carefully structured.

b. The number of raters will not be less than 2 for each case.

c. The candidates should be put at ease in order to make the results both more valid and reliable.

d. Each interview will be recorded for scoring and future reference.

e. Scoring will be discrete rather than holistic.

3- A self- esteem questionnaire was distributed among the participants who will be asked to fill them out. The questioners then will be collected for purpose of analysis.

It should be mentioned that a pilot study was conducted to determine the extent of time required for the completion of the questionnaire and OPT and also to decide whether or not the items and the scale require any modifications.

\section{RESULTS AND DISCUSSION}

In this study, as mentioned before, an attempt was made to find answers to the three questions concerning the relationship between the three factors of self-esteem, age, gender and speaking skills. Appropriate statistical procedures were followed to obtain the required responses for each question. Below each hypothesis and its results will be discussed separately.

Since the scores of speaking skills of participants were given by two raters, estimating the inter-rater reliability was necessary to determine whether or not their given scores are reliable. Table1 shows correlations between the scores of the raters in relation to pronunciation, vocabulary, structure, fluency and comprehensibility are significant at levels below .05. However, this level of significance is reduced to .08 regarding ratings on participants' achievements on vocabulary, which, obviously, means that in all cases, except one, the raters were in agreement over the achievements of the participants 
TABLE 1.

PEARSON CORRELATION TEST FOR INTER- RATER RELIABILITY

\begin{tabular}{|l|l|l|l|l|l|}
\hline & Pronunciation & Structure & Vocabulary & Fluency & Comprehensibility \\
\hline Pearson Correlation & 0.495 & 0.499 & 0.399 & 0.726 & 0.563 \\
\hline Sig. (2-tailed) & 0.027 & 0.025 & 0.081 & 0.000 & 0.010 \\
\hline
\end{tabular}

The first hypothesis formulated in this paper was:

1- There is no relationship between self-esteem and speaking skills of EFL learners.

Concerning this main question, multivariate tests were run. Tables 2. and 3. show the results. The findings show that it is safe to conclude that that there is a significant relationship between self-esteem and fluency (Table 3.) whereas the other components of oral production do not meet the requirements of being statistically significant.

TABLE2.

Multivariate Tests

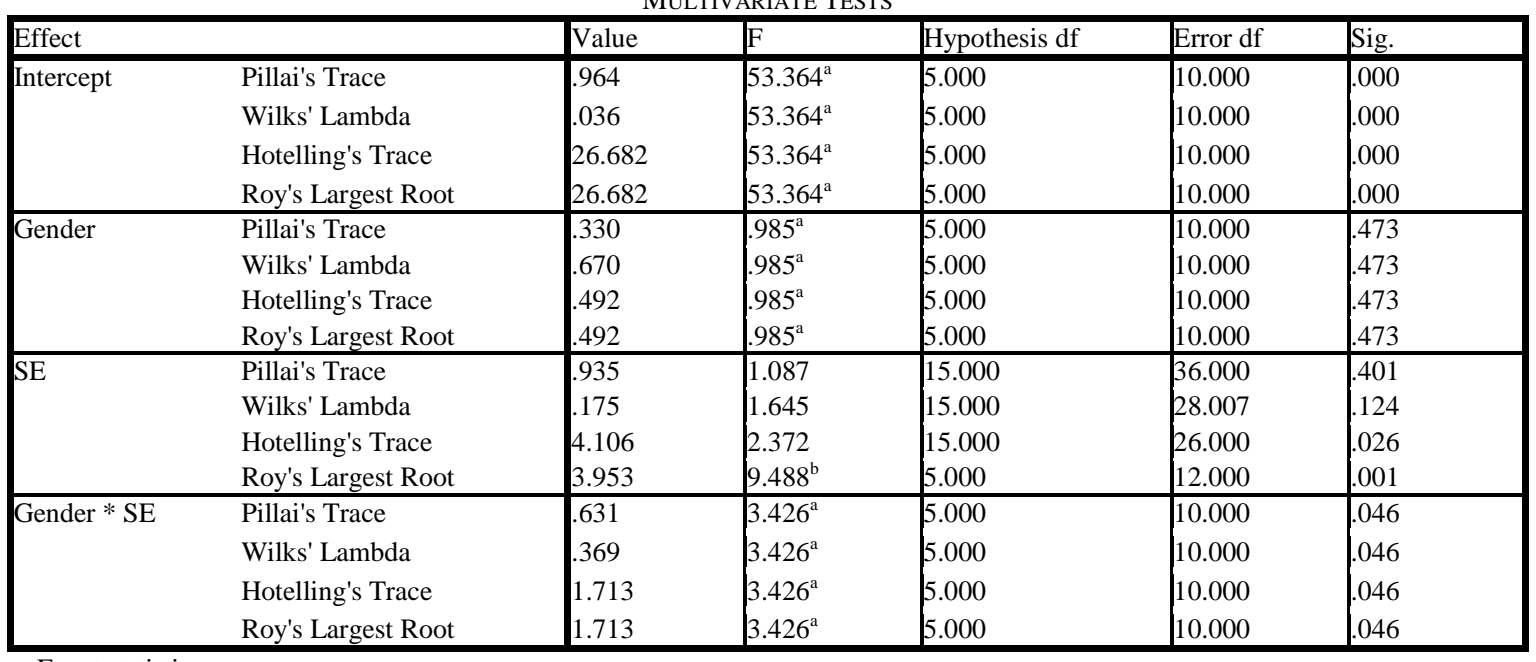

a. Exact statistic

b. The statistic is an upper bound on $\mathrm{F}$ that yields a lower bound on the significance level.

c. Design: Intercept + Gender $+\mathrm{SE}+$ Gender $* \mathrm{SE}$ 
TABLE3.

TESTS OF BETWEEN-SUBJECTS EFFECTS

\begin{tabular}{|c|c|c|c|c|c|c|}
\hline Source & Dependent Variable & $\begin{array}{c}\text { Type III Sum of } \\
\text { Squares } \\
\end{array}$ & $\mathrm{df}$ & Mean Square & $\mathrm{F}$ & Sig. \\
\hline \multirow[t]{5}{*}{ Corrected Model } & Pronunciation & $1.000^{2}$ & 5 & .200 & .404 & .838 \\
\hline & Structure & $.957^{\circ}$ & 5 & .191 & .168 & .970 \\
\hline & Vocabulary & $.640^{\mathrm{c}}$ & 5 & .128 & .220 & .948 \\
\hline & Fluency & $8.715^{\mathrm{d}}$ & 5 & 1.743 & 3.630 & .026 \\
\hline & Comprehensibility & $2.749^{\mathrm{e}}$ & 5 & .550 & .554 & .733 \\
\hline \multirow[t]{5}{*}{ Intercept } & Pronunciation & 101.869 & 1 & 101.869 & 205.573 & .000 \\
\hline & Structure & 141.411 & 1 & 141.411 & 123.788 & .000 \\
\hline & Vocabulary & 122.508 & 1 & 122.508 & 210.193 & .000 \\
\hline & Fluency & 118.120 & 1 & 118.120 & 246.001 & .000 \\
\hline & Comprehensibility & 156.133 & 1 & 156.133 & 157.382 & .000 \\
\hline \multirow[t]{5}{*}{ Gender } & Pronunciation & .460 & 1 & .460 & .927 & .352 \\
\hline & Structure & .094 & 1 & .094 & .083 & .778 \\
\hline & Vocabulary & .204 & 1 & .204 & .350 & .563 \\
\hline & Fluency & .131 & 1 & .131 & .272 & .610 \\
\hline & Comprehensibility & .314 & 1 & .314 & .317 & .583 \\
\hline \multirow[t]{5}{*}{$\mathrm{SE}$} & Pronunciation & .697 & 3 & .232 & .469 & .709 \\
\hline & Structure & .341 & 3 & .114 & .100 & .959 \\
\hline & Vocabulary & .329 & 3 & .110 & .188 & .903 \\
\hline & Fluency & 5.175 & 3 & 1.725 & 3.593 & .041 \\
\hline & Comprehensibility & .507 & 3 & .169 & .170 & .915 \\
\hline \multirow[t]{5}{*}{ Gender * SE } & Pronunciation & .389 & 1 & .389 & .785 & .391 \\
\hline & Structure & .094 & 1 & .094 & .083 & .778 \\
\hline & Vocabulary & .040 & 1 & .040 & .068 & .798 \\
\hline & Fluency & 2.531 & 1 & 2.531 & 5.271 & .038 \\
\hline & Comprehensibility & .314 & 1 & .314 & .317 & .583 \\
\hline \multirow[t]{5}{*}{ Error } & Pronunciation & 6.938 & 14 & .496 & & \\
\hline & Structure & 15.993 & 14 & 1.142 & & \\
\hline & Vocabulary & 8.160 & 14 & .583 & & \\
\hline & Fluency & 6.722 & 14 & .480 & & \\
\hline & Comprehensibility & 13.889 & 14 & .992 & & \\
\hline \multirow[t]{5}{*}{ Total } & Pronunciation & 270.750 & 20 & & & \\
\hline & Structure & 345.000 & 20 & & & \\
\hline & Vocabulary & 313.000 & 20 & & & \\
\hline & Fluency & 278.250 & 20 & & & \\
\hline & Comprehensibility & 390.750 & 20 & & & \\
\hline \multirow[t]{5}{*}{ Corrected Total } & Pronunciation & 7.937 & 19 & & & \\
\hline & Structure & 16.950 & 19 & & & \\
\hline & Vocabulary & 8.800 & 19 & & & \\
\hline & Fluency & 15.437 & 19 & & & \\
\hline & Comprehensibility & 16.638 & 19 & & & \\
\hline
\end{tabular}

a. R Squared $=.126$ (Adjusted R Squared $=-.186)$

b. R Squared $=.056$ (Adjusted R Squared $=-.281$ )

c. R Squared $=.073$ (Adjusted R Squared $=-.258$ )

d. R Squared $=.565$ (Adjusted R Squared $=.409$ )

e. R Squared $=.165$ (Adjusted R Squared $=-.133$ )

This finding is in part in line with the findings of Niki Maleki \& Mohammadi (2009). They found that the more successful learners regarding the oral communication had higher self-esteem than the less successful ones in performing oral communication tasks.

Figure1. shows the extent to which degrees of self-esteem affect mean fluency

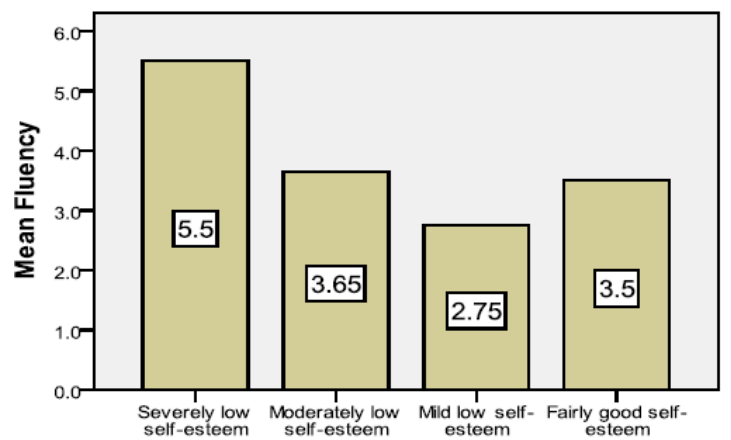

Self-Esteem

Figure1.Bargragh for mean fluency and self-esteem 
The second hypothesis sought to determine whether or not there was a relationship between gender and speaking skills. More specifically the hypothesis was:

2- There is no relationship between gender and speaking skills among EFL learners.

Regarding this hypothesis as statistics in the multivariate tests (Tables 2 and 3) clearly show there is no meaningful associations between these two factors as results show no significant difference at the 0.05 level of significant. However as seen in figure 2. different weights of self-esteem impact fluency in production rather differently although not significantly. This finding is in agreement with the findings of Gorjian, Moosavian and Shahramiri (2011). In their study concerning the effect of oral summery of short stories on male/female learners' speaking proficiency, no significant relationship was found between gender and the speaking skills.

Figure 2. also shows that as males' level of self-esteem increases, their speaking abilities also improve. This is the reverse in the case of females except when we move from mild low self-esteem to fairly good self-esteem. These contrastive results can be due to the fact that there were only 5 males compared to fifteen females.

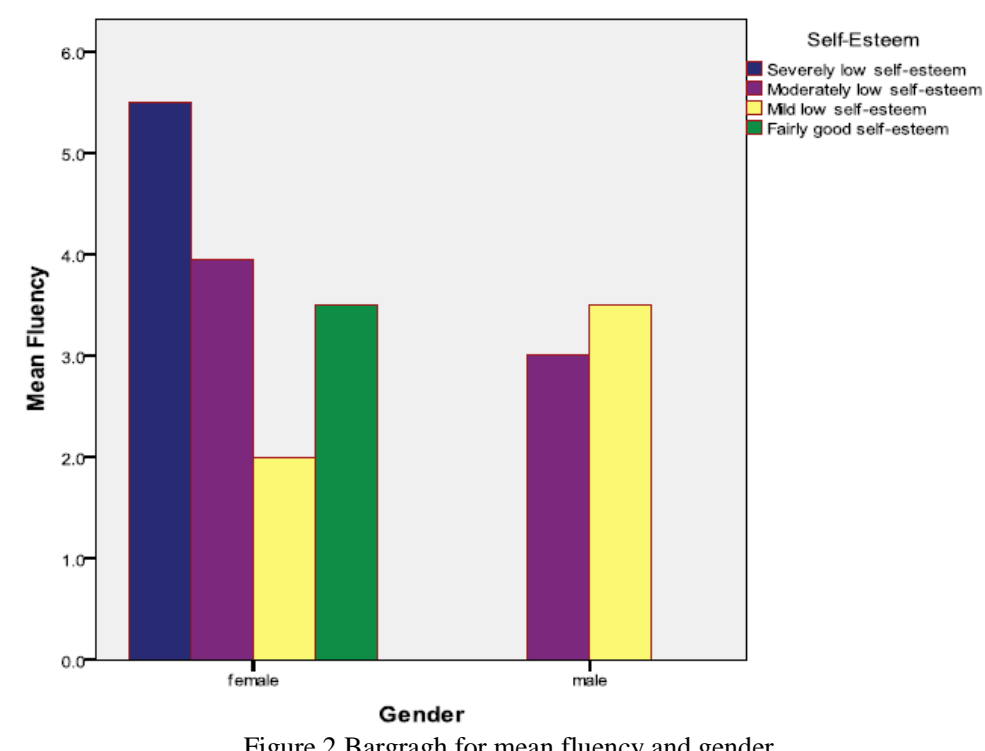

Figure 2.Bargragh for mean fluency and gender

Hypothesis three was concerned with whether or not there was a linear relationship between age and speaking skill. To be more specific it was stated as the following:

3- There is no relationship between age and speaking skill among EFL learners.

A simple linear regression line by using the appropriate statistical method was run to determine the case. Figure 3. below shows that there is a negative relationship between age and speaking skills, that is ,younger participants outperform their older peers in all sub-skills of production. This is in line with what Carroll's (2008) views. He believes that as the age of learner increases, learning a second or foreign language becomes more difficult. Also the results of this study supports the findings of Hakuta, Bialystok and Wiley (2003) and is also in agreement with Romero's (2006) position that age affects the development of speaking abilities negatively.

This can be due to some factors including perhaps higher motivation on the part of younger participants and higher aspiration for their future. It can also be due to exposure to better materials, better technologies and improved methods of teaching normally available recently for the new generation of learners.

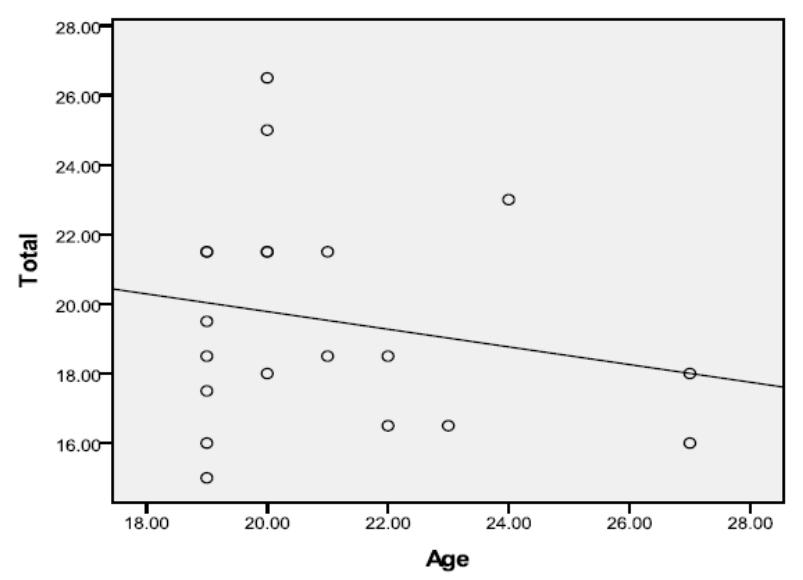

Figure 3. Scatter gram showing the relationship between age and achievement on oral production. 
As Table 4. shows, the level of significant is much larger than what can be statistically significant to determine the effect of age on speaking skill.

TABLE4.

TEST OF ANOVA BETWEEN AGE AND SPEAKING SKILL

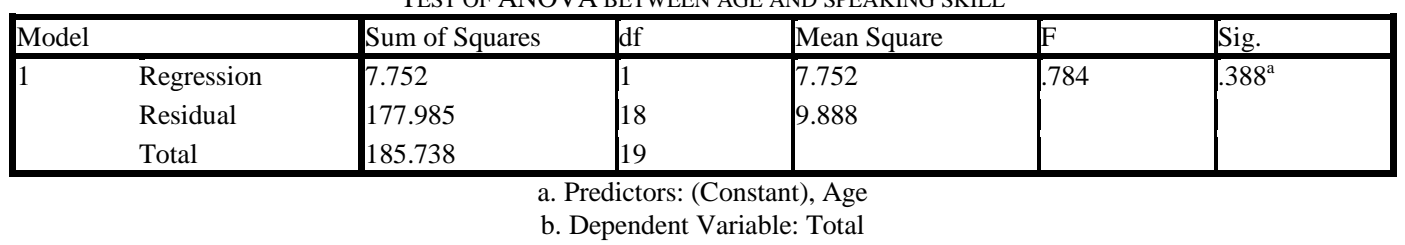

\section{CONCLUSIONS AND IMPLICATIONS}

As Erikson (1963) maintains we always look for stable identity, covering our knowledge of who we are, what our weaknesses and strengths are, and, in short, how we evaluate ourselves. This evaluation of the self in literature today is referred to as self-esteem. Many studies have been conducted to determine the relationship between how one evaluates himself and his success in academic studies. While some have reported that there is no significant relationship between the two, others have shown that the higher the self esteem, the greater the chances of success in academic achievement. The main concern of this study was to see if such a relationship could be detected among Iranian EFL learners' achievements in oral production, covering the five components of vocabulary, grammar, pronunciation, comprehension and fluency, on the one hand, and how they evaluate themselves, on the other.

The results showed that fluency was the only factor which was significantly affected by self-esteem, although the other sub-skills of oral production showed various degrees of influence, yet not statistically significant. The findings may be interpreted to mean that those who enjoy higher levels of self-esteem are more sociable, more risk taking and more prepared to share their views with others regardless of whether, lexically or grammatically, they produce what can be regarded as accurate or standard or even correct English. This means that fluency for the person who has a positive view of his worth comes before accuracy, something which can perhaps take care of itself in the process of communication.

In this study, a negative relationship was found between speaking skills and age, that is, younger learners outperformed the older ones. This difference can be traced back to the availability of richer materials and better exposure to the language through the different sources such as the Internet and foreign mass media. It seems that younger students are more interested in using the developing technology provided these days for the improvement of language education. According to Carroll (2008) biological changes, environmental factors, cognitive factors or the combination of factors might be responsible for the advantage that younger learners show in some studies .Regarding the relationship between gender and speaking skills no statistically significant relationship was found. This can be due to the fact that both male and females are exposed to the same materials, the same methods and are usually taught by the same teacher.

This paper might have some suggestions for language teachers. As it was shown, the level of learners' self-esteem has a significant effect on the fluency of learners' speaking. So it might be helpful if teachers pay more attention to their students' level of self-esteem and try to enhance it. Also considering the age of students is important for decision making purposes since it affects performance. Knowing this, teachers might be less critical on the performance of older learners and give them more time and make the necessary changes in their approaches to enable them to catch up with the younger ones. The factors of self-esteem, age should also be considered by materials developers.

English language learners could also benefit from the findings of this study to become aware of the impact of self esteem and age and make appropriate decisions to enhance their self-esteem and also to begin learning a second language at an earlier age.

\section{REFERENCES}

[1] Bong, M. \& Clark, R. E. (1999). Comparison between self-concept and self-efficacy in academic motivation research. Educational psychologist, 34, 3, 139-153.

[2] Carroll, D. W., (2008). Psychology of language. CA: Thomson higher education.

[3] Carter, R., \& Nunan, D. (2001). The Cambridge guide to teaching English to speakers of other languages. Cambridge: Cambridge University Press.

[4] Celce-Murcia, M. (1991). Teaching English as a second or foreign language. Boston: Heinle \& Heinle publishers.

[5] Chapman, J. W. \& Tunmer, W. E. (1997). A longitudinal study of beginning reading achievement and reading self-concept, British Journal of Educational Psychology, 67, 279-291.

[6] Choi, N. (2005). Self-efficacy and self-concept as predictors of college students' academic performance, Psychology in the Schools, Vol.42, No. 2 pp.197-205.

[7] Chomsky, N. (1959). Review of B.F. Skinner, Verbal Behavior. Language, 35, 26-58.

[8] Claes, M. T. (1999). Women, men \& management style. International Labour Review 138 (4), 431-446. http:// global.umi.com/pqdweb?( Accessed 28 November, 2001). 
[9] De Fraine, B., Van Damme, J. \& Ongheda, P. (2007). A longitudinal analysis of gender differences in academic self-concept and language achievement: A multivariate multilevel latent growth approach. Contemporary Educational Psychology, 32, 132150.

[10] Erikson, E. H. (1963). Childhood and society (2nd ed.). New York: Norton.

[11] Felix, W. Sascha, (1988). UG-Generated knowledge in adult second language acquisition, In Suzanne Flynn and Wayne O’Neil (ed). Linguistic Theory in Second Language Acquisition. Dordrecht: Kluwer Academic Publishers, pp.277-279.

[12] FLETA, Teresa (2006). Stepping Stones for teaching "English L" in the early years, en Mitchell-Shuitevoerder and S. Mourao (eds.), Teachers and Young Learners. Research in our classrooms. Canterbury: IATEFL. 43-50.

[13] Gonzalez-Pienda, J.A., Nunez, J.C.;Gonzalez- Pumariega,S. A., (2000). Autoconcepto, proceso deatribucioncausal y mets academicas en ninos con y sin dificultades deaprendizaje.[Self-concept, causal attribution process and academic goals in children with and without learning disability].Psicothema,12(4),548-556.

[14] Gorjian, B. \& Moosavinia, R. Shahramiri, P. (2011). Effects of Oral Summary of Short Stories on Male/Female Learners' Speaking Proficiency: High vs. Low Achievers. Iranian EFL Journl,7, pp 34-50

[15] Hakuta, K., Bialystok, E., \& Wiley, E. (2003). Critical evidence: A test of the critical-period hypothesis for second-language acquisition. Psychological Science, 14, 31-38.

[16] Hayati, M. \& Ostadian, M. (2008). The Relationship between Self-esteem and Listening Comprehension of EFL Students. http//bibliotecavirtualut.suagm.edu/Glossa2/Journal/Jun2008/The_reltion ship_ between_ self- esteem.pdf. (accessed February 7, 2008).

[17] Helmke, K. G. \& Van Aken, M. A. G. (1995). The causal ordering of academic achievement and self-concept of ability during elementary school: A longitudinal study, Journal of Educational Psychology, Vol.87, pp.624-637.

[18] Huitt, W. (2004). Self-concept and self-esteem. Educational Psychology Interactive. Retrieved from http://chiron.valdosta.edu/whuitt/col/regsys/self.html.

[19] Hunter, D. \& Gambell, T. \& Randhawa, B. (2005). Gender gaps in group listening and speaking: Issues in social constructivist approaches to teaching and learning. Educational Review, 57, $329-355$.

[20] Hymes, D. (1972). On Communicative Competence, in J. B. Pride and J. Holmes (eds.): Sociolinguistics. Harmondsworth, Middlesex: Penguin Education, 269- 93.

[21] Kuhl, K. P. (2004). Early Language Acquisition: Cracking the Speech Code. Nature Reviews Neuroscience, 5, 831-843.

[22] Kamarzarrin, H. (1994). A study of self-esteem third grade students of governmental and private high schools of Dezful. Unpublished M.A thesis, College of Educational Science, Shiraz University, Iran.

[23] Klein, W. (1986). Second Language Acquisition. Cambridge: Cambridge University Press, pp. 3-32.

[24] Kurtz-Costes, B. E. \& Schneider, W. (1994). Self-concept, attributional beliefs, and school achievement: A longitudinal analysis, Contemporary Educational Psychology, Vol.19, pp.199-216.

[25] Lenneberg, E. (1967). The Biological Foundations of Language. New York: Wiley.

[26] Lightbown and Spada. (2006). How Languages are learned. Oxford: Oxford University Press.

[27] Liu H. J. (2008). The relationship between EFL students' academic self-concept and language performance. Feng Chia Journal of Humanities and Social Sciences.17, 165-184.

[28] Marsh, H. W. (1990). The structure of academic self-concept: The Marsh/ Shavelson model, Journal of Educational Psychology, Vol.82, No.4, pp.623-636.

[29] Marsh, H. W., Kong, C.-K. \& Hau, K.-T. (2001). Extension of the internal/external frame of reference model of self-concept formation: Importance of native and nonnative language for Chinese students, Journal of Educational Psychology, Vol.93, No.3, pp.543-553.

[30] Marsh, H. W., Relich, J. D. \& Smith, I.D. (1983). Self-concept: The construct validity of interpretations based upon the SDQ, Journal of Personality and social psychology, Vol. 45, No.1, pp.173-187.

[31] Marsh, H. W. \& Yung, A.S. (1998). Longitudinal structure equation models of academic self-concept and achievement: Gender differences in the development of math and English constructs, American Educational Research Journal, 35, $705-738$.

[32] Maslow, A. (1970). Motivation and personality. New York: Harper and Row.

[33] Miyagawa, L. (2010). What is the difference between self-esteem and self confidence? Retrieved from 20/02/2011)

[34] Nezu, C. M., \& Nezu, A. M. (2003). Awakening self-esteem: Psychological and spiritual techniques for improving your wellbeing. Oakland, CA: New Harbinger.

[35] Niki Maleki, M., Mohammadi, A., M. (2009).Self-esteem and Anxiety of Iranian EFL Learners in Oral Communication Tasks. Journal of linguistic studies, 2 (2).47-54.

[36] Owayed El-Anzi, F. (2005). Academic achievement and its relationship with anxiety, self-esteem, optimism, and pessimism in Kuwaiti students. Social Behavior and Personality, 33(1), 95-104.

[37] Romero, B. N. (2006). Improving speaking skill. Encuentro. 18, pp. 86-90

[38] Spolsky, B. (1989). Conditions for second language learning. Oxford: Oxford University Press.

[39] Stern, H.H. (1983). Fundamental concepts of language teaching. Oxford: Oxford University Press.

[40] Stern, D. N. (1995). Self/other differentiation in the domain of intimate socio-affective interaction: Some considerations. In P. Rochat (Ed.), The self in infancy: Theory and research (pp. 419-429). Amsterdam: North Holland Elsevier.

Bahareh Koosha is an M.A. student of TEFL at Isfahan University, Iran. Her main areas of research are psycholinguistics, teaching methodologies and discourse analysis. 
Saeed Ketabi holds a PhD in Applied Linguistics from the University of Cambridge (UK). He is currently teaching various ELT courses at graduate levels at the Department of English, University of Isfahan. He has published and presented several papers in his field.

Zohreh Kassaian holds a Ph.D. in TEFL, is currently teaching and researching various topics at graduate and undergraduate levels at the University of Isfahan. Her areas of interests are psycholinguistics, theories of learning, translation and language teaching and has published and presented papers widely in these areas.

Dr. Kassaian has written a book series used in Language Laboratory for EFL students. She is, at the moment, the president of Sobh Sadegh University. 